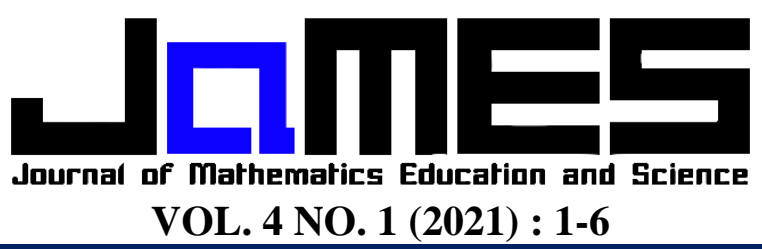

p-ISSN: 2621-1203 | https://doi.org/10.32665/james.v4i1.143

e-ISSN: 2621-1211

\title{
PENGARUH PEER TUTORING METHOD MENGGUNAKAN BUKU SAKU DIGITAL TERHADAP PEMAHAMAN KONSEP MATEMATIS
}

\author{
Agus Pamuji ${ }^{1}$, Rizki Wahyu Yunian Putra ${ }^{2}$, Agus Pahrudin 3 \\ Universitas Islam Negeri Raden Intan Lampung, Amzicolek@gmail.com ${ }^{1}$ \\ Universitas Islam Negeri Raden Intan Lampung, rizkiwahyuyp@ radenintan.ac.id ${ }^{2}$ \\ Universitas Islam Negeri Raden Intan Lampung, pahrudin@ radenintan.ac.id ${ }^{3}$ \\ Received : 13 Juni 2020, Revised : 25 April 2021, Accepted : 26 April 2021 \\ (C) Mathematics Education Unugiri 2021
}

\begin{abstract}
This study aimed to determine the increase in understanding of mathematical concepts using the Peer Tutoring method and digital pocketbooks. The research conducted was experimental research. This study used random sampling with cluster random sampling technique. The data collection technique is using a test (essay). The data analysis technique in this study is the normality gain (N-gain). The data analysis technique applied to test the hypothesis in this study was the ANOVA of the same cell path. The results of data analysis and hypothesis testing that have been carried out can be concluded that there is an effect of Peer Tutoring Method learning using learning media assisted by digital pocketbooks on the ability to understand mathematical concepts.
\end{abstract}

Keywords : Digital pocketbook, Concept comprehension, Peer Tutoring Method

\begin{abstract}
Abstrak
Tujuan dari penelitian ini untuk mengetahui peningkatan pemahaman konsep matematis dengan Peer Tutoring Method dan buku saku digital. Penelitian yang dilakukan adalah penelitian eksperimen. Penelitian ini menggunakan random sampling dengan teknik Cluster Random Sampling. Teknik pengumpulan data adalah menggunakan Tes (essay). Teknik analisis data pada penelitian ini adalah dengan normalitas gain ( $\mathrm{N}$-gain). Teknik analisis data-yang diterapkan untuk menguji hipotesis dalam penelitian ini adalah dengan ANOVA satu jalan sel sama. Hasil analisis data dan pengujian hipotesis yang telah dilakukan dapat disimpulkan bahwa adanya pengaruh penggunaan pembelajaran Peer Tutoring Method menggunakan media pembelajaran berbantu buku saku digital terhadap kemampuan pemahaman konsep matematis.
\end{abstract}

Kata Kunci : Buku Saku Digital, Pemahaman Konsep, Peer Tutoring Method

\section{Pendahuluan}

Penunjang dan pengembangkan ilmuilmu pengetahuan diperlukan untuk bekal terjun dan bersosialisasi dalam kehidupan bermasyarakat [1]. Ada terdapat berbagai pengetahuan, salah satunya adalah matematika. Kualitas sumber daya manusia bisa ditingkatkan dengan proses pembelajaran yang diikuti diberbagai tingkat Pendidikan [2]. Pernyataan tersebut menggambarkan bahwaemahaman konsep memegang peranan penting dalam pembelajaran matematika [3]. Berdasarkan penelitian yang dilakukan oleh banyak peserta didik kesulitan memahami konsep matematika [4]. Pemahaman konsep merupakan bekal awal atau dasar [5]. Serta langkah penting untuk mempelajari matematika. Pembaharuan yang diinginkan merupakan pembaharuan metode pembelajaran yang mengembangkan kemampuan pemahaman konsep matematis Salah satu Metode pembelajaran yang dimaksud adalah 
Peer Tutoring method dengan pendekatan mengajar yang menuntut peserta didik mampu mengajar peserta didik yang lain [6]. Kelebihan Peer Tutoring method diantaranya: Menghilangkan rasa ketakutan karna perbedaan usia, status, dan latar belakang yang biasa terjadi antara Peserta didik dan guru. Lebih mungkin terjadi pembelajaran personal antara tutor sebaya. Tutor sendiri akan mendapatkan manfaat dari menjadi tutor teman sebaya [7]. Penggunaan teknologi informasi dan komunikasi di dalam dunia pendidikan terus berkembang dengan memanfaat kan media digital [8]. Buku saku digital secara elektronis melalu computer berupa file dengan format pdf ataupun dengan bentuk format htm lebih mudah dalam mempergunakannya dan mudah dalam mengolah security sebagai media pembelajaran [9]. Adapun penelitian ini belum pernah dilakaukan sebelumnya, maka dilakukannya penelitian ini dengan tujuan untuk meningkatkan pemahaman konsep matematis dengan Peer Touring Method berbantuan buku saku digital.

\section{Metode Penelitian}

Penelitian yang dilakukan adalah penelitian eksperimen. Jenis eksperimen yang digunakan eksperimen semu, sehingga hasil penelitian tidak murni dari eksperimen yang dilakukan. Penelitian ini dilaksanakan di UPT SMPN di Bandar Lampung kelas VII, pada semester ganjil pada tahun ajaran 2019/2020. Waktu yang digunakan oleh peneliti untuk melakukan penelitian yaitu pada Semester Ganjil tahun ajaran 2019/2020. Populasi penelitian ini seluruh Peserta didik kelas VII yang berada di UPT SMPN di Bandar Lampung yang terdiri dari 4 kelas, Didalam penelitian ini digunakan random sampling dengan teknik cluster random sampling.

Teknik Pengumpulan Data ialah Tes (essay) untuk melihat pengaruh Peer Tutoring method menggunakan buku saku digital terhadap kemampuan pemahaman konsep. Sebelum dilakukan penelitian dilakukan teknik analisis uji coba instrumen penelitian dengan uji validitas, uji reliabilitas uji tingkat kesukaran uji daya beda. teknik analisis data dengan normalitas gain ( $\mathrm{N}$-gain).

Uji kenormalan dengan adalah uji Liliefors sedangkan uji homogenitas variansi digunakan metode Bartlett. Teknik analisis data-yang diterapkan untuk menguji hipotesis dalam penelitian ini dengan ANOVA satu jalan sel sama. Rumusan hipotesis statistik:

$\mathrm{H}_{0}: \mu_{1}=\mu_{2}=\mu_{3}$ (Tidak ada pengaruh penggunaan metode pembelajaran Peer Tutoring method menggunakan buku saku digital terhadap pemahaman konsep)

$\mathrm{H}_{1}: \mu_{\mathrm{i}} \neq \mu_{\mathrm{j}}$ (ada sekurang-kurangnya sepasang nilai tengah $\mu_{\mathrm{i}}$ dan $\mu_{\mathrm{j}}$ yang tidak sama, maksudnya yakni ada pengaruh penggunaan Peer Tutoring method menggunakan buku saku digital terhadap pemahaman konsep).

\section{Pembahasan}

Pretest dimaksudkan untuk mengetahui keadaan awal antara kelompok ekperimen dan kelompok kontrol. Sebelum proses pembelajaran dilaksanakan pada empat kelas terlebih dahulu diadakan pretest untuk memperoleh data awal. Data hasil pretest kemampuan pemahaman konsep matematis dapat disajikan dalam grafik. Adapun deskripsi data hasil pretest kemampuan pemahaman konsep matematis siswa pada materi bangun datar terangkum dalam Tabel 1.

Tabel 1. Hasil Pretest Pemahaman Konsep

\begin{tabular}{|c|c|c|c|c|c|c|c|}
\hline \multirow[t]{2}{*}{ Kelompok } & \multirow[t]{2}{*}{$\mathbf{X}_{\max }$} & \multirow[t]{2}{*}{$\mathbf{X}_{\min }$} & \multicolumn{3}{|c|}{$\begin{array}{c}\text { Ukuran } \\
\text { Tendensi } \\
\text { Sentral }\end{array}$} & \multicolumn{2}{|c|}{$\begin{array}{c}\text { Ukuran } \\
\text { Variansi } \\
\text { Kelompok }\end{array}$} \\
\hline & & & $x$ & $\mathbf{M}_{0}$ & $\mathbf{M}_{\mathbf{e}}$ & $\mathbf{R}$ & Sd \\
\hline Eksp 1 & 64 & 43 & 54,429 & 61 & 54 & 21 & 7,596 \\
\hline Eksp 2 & 61 & 43 & 52,473 & 50 & 52 & 18 & 5,783 \\
\hline Eksp3 & 64 & 50 & 55,220 & 54 & 54 & 14 & 4,430 \\
\hline Kontrol & 68 & 43 & 57,755 & 61 & 61 & 25 & 6,938 \\
\hline
\end{tabular}

Berdasarkan Tabel 1 dapat dilihat bahwa nilai hasil tes sebelum proses pembelajaran dengan nilai tertinggi $\left(X_{\max }\right)$ pada kelas eksperimen 1 sebesar 64, eksperimen 2 sebesar 61, eksperimen 3 sebesar 64 dan kelas 
kontrol sebesar 68, sedangkan nilai terendah $\left(X_{\text {min }}\right)$ untuk kelas ekperimen 1 adalah 43, eksperimen 2 adalah 43, eksperimen 3 adalah 50 dan kelas kontrol adalah 43. Uji peningkatan kemampuan pemahaman konsep matematis siswa digunakan untuk melihat seberapa besar metode pembelajaran peer tutoring berbantu buku saku digital pada kelas eksperimen dan model pembelajaran konvensional pada kelas kontrol memberikan pengaruh pada kemampuan pemahaman konsep matematis siswa. Data hasil posttest kemampuan pemahaman konsep matematis siswa dapat disajikan dalam diagram. Adapun deskripsi data hasil posttest kemampuan pemahaman konsep matematis peserta didik pada materi bangun datar terangkum dalam tabel 2 .

Tabel 2. Hasil Posttest Pemahaman Konsep

\begin{tabular}{|c|c|c|c|c|c|c|c|}
\hline \multirow[t]{2}{*}{ Kel } & \multirow[t]{2}{*}{$\mathbf{X}_{\max }$} & \multirow[t]{2}{*}{$\mathbf{X}_{\min }$} & \multicolumn{3}{|c|}{$\begin{array}{c}\text { Ukuran } \\
\text { Tendensi } \\
\text { Sentral }\end{array}$} & \multicolumn{2}{|c|}{$\begin{array}{c}\text { Ukuran } \\
\text { Variansi } \\
\text { Kelompok }\end{array}$} \\
\hline & & & $x$ & $\mathbf{M}_{0}$ & $\mathbf{M}_{\mathbf{e}}$ & $\mathbf{R}$ & Sd \\
\hline Eksp 1 & 89 & 71 & 79,000 & 82 & 79 & 18 & 5,583 \\
\hline Eksp 2 & 82 & 68 & 75,137 & 75 & 75 & 14 & 4,233 \\
\hline Eksp3 & 82 & 71 & 76,648 & 79 & 77 & 11 & 3,811 \\
\hline Kontrol & 79 & 61 & 74,176 & 75 & 75 & 18 & 5,082 \\
\hline
\end{tabular}

Berdasarkan Tabel 2 di atas dapat dilihat bahwa nilai posttest dengan nilai tertinggi $\left(X_{\max }\right)$ pada kelas eksperimen 1 yaitu sebesar 89 , eksperimen 2 yaitu 82 , eksperimen 3 yaitu 82 dan kelas kontrol yaitu 79, sedangkan nilai terendah $\left(X_{\min }\right)$ untuk kelas eksperimen 1 adalah 71 , eksperimen 2 adalah 68 , eksperimen 3 adalah 71 dan kelas kontrol adalah 61 .

Selanjutnya untuk melihat manakah metode pembelajaran yang secara signifikan memberi peningkatan yang berbeda terhadap kemampuan pemahaman konsep matematis siswa maka dilakukan uji lanjut pasca anova Ngain menggunakan metode Scheffe dengan menggunakan SPSS berikut ini: Kelas dengan menggunakan Metode peer tutoring berbantu tutor sebaya terlihat lebih aktif dan senang saat proses pembelajaran. Keaktifan peserta didik muncul saat di berikan tugas dengan menggunakan buku saku digital dan metode peer tutoring. Berbeda dengan kelas dengan menggunakan metode peer tutoring, hal ini karena kelas yang mengunakan metode peer tutoring hanya di beri tugas dan mereka mengerjakan tugas perorangan, kemudian setelah peserta didik selesai mengerjakan tugas mereka di tunjuk oleh guru untuk menjelaskan hasil tugas mereka dihadapan guru. Kelas dengan menggunakan metode peer tutoring berbantu buku saku digital lebih baik dari kelas dengan menggunakan metode peer tutoring, dikarenakan metode peer tutoring hanya menuntut peserta didik untuk mengerjakan tugas dengan temannya, dan kebanyakan dari mereka mengerjakan tugasnya di barengkan dengan mengobrol satu sama lain, jadi tidak fokus untuk mengerjakan tugas. Kelas dengan menggunakan metode peer tutoring berbantu buku saku digital lebih baik dibandingkan dengan kelas yang menggunakan model pembelajaran konvensional dikarenakan model pembelajaran konvensional peserta didik terlihat pasif, karena jenuh dengan cara ceramah dalam penyampaian materi.

Pada proses pembelajaran metode peer tutoring maupun pembelajaran dengan buku saku digital diketahui bahwa ada peserta didik yang tidak dapat mempresentasikan hasil diskusinya karena kurangnya alokasi waktu, pada proses pembelajaran metode peer tutoring maupun buku saku digital berjalan dengan baik, hanya saja peserta didik yang aktif mengemukakan ide-idenya hanya peserta didik yang memiliki kemampuan yang tinggi saja. Kelas yang menggunakan metode peer tutoring lebih baik dengan kelas yang menggunakan model pembelajaran konvensional kerena model pembelajaran Konvensional membuat peserta didik terlihat pasif saat pembelajaran yang mengakibatkan kurangnya semangat dan motivasi untuk menerima materi yang di berikan oleh peneliti.

Kelas dengan menggunakan buku saku digital lebih baik dibandingkan dengan model pembelajaran konvensional dikarenakan model pembelajaran konvensional membuat peserta 
didik terlihat pasif saat pembelajaran yang mengakibatkan kurangnya semangat dan motivasi untuk menerima materi yang di berikan oleh peneliti.

Penelitian ini dilaksanakan di UPT SMPN di Bandar Lampung. Penulis mengambil sampel sebanyak 4 kelas yaitu kelas VIIA,VIIB, VIIC, dan VIID. Sebagai kelas eksperimen 1 VIIA yang diberi perlakuan menggunakan metode peer tutoring berbantu buku saku digital, kelas eksperimen 2 VIIB yang diberi perlakuan metode peer tutoring dan kelas eksperimen 3 VIIC yang diberi perlakuan dengan buku saku digital, VIID sebagai kelas kontrol dimana proses pembelajarannya menggunakan pembelajaran konvensional. Adapun jumlah siswa pada kelas eksperimen berjumlah 77 peserta didik dan jumlah peserta didik kelas kontrol berjumlah 25 siswa, sehingga total sampel seluruhnya berjumlah 102 peserta didik. Penelitian ini terdiri dari variabel bebas (X) yaitu metode peer tutoring berbantu buku saku digital, serta variabel terikat (Y) yaitu kemampuan pemahaman konsep matematis.

Materi yang diajarkan pada penelitian ini adalah materi segitiga dan segiempat, kemudian untuk mengumpulkan datadata untuk pengujian Anova, penulis menerapkan metode pembelajaran peer tutoring berbantu buku saku digital dalam materi segitiga dan segiempat sebanyak 4 kali pertemuan. Dalam penelitian ini penulis memberikan pretest dan postest kepada peserta didik yang dilakukan diawal dan diakhir pertemuan. Pretest dan postest yang diberikan kepada peserta didik berupa soal tes uraian untuk mengetahui ada atau tidaknya peningkatan kemampuan pemahaman konsep matematis. Soal tes tersebut adalah instrumen yang sudah diuji validitas, reliabilitas, tingkat kesukaran dan daya bedanya.

Sebelum penulis melakukan proses pembelajaran, peserta didik kelas eksperimen dan kelas kontrol sudah terlebih dahulu dilakukan uji Pretest untuk melihat bahwa keempat kelas memiliki kemampuan yang sama. Hasil yang diperoleh ternyata empat kelas memiliki kemampuan yang sama, maka selanjutnya peneliti akan melakukan proses tahap pembelajaran.

Pada kelas eksperimen 1, peneliti menerapkan metode peer tutoring berbantu buku saku digital. Pertemuan pertama peneliti melaksanakan perlakuan metode peer tutoring berbantu buku saku digital sesuai dengan langkah-langkah pada RPP, namun peserta didik masih belum memahami pelaksanaan metode peer tutoring berbantu buku saku digital dan sering terjadi kegaduhan didalam kelas mengakibatkan kelas kurang kondusif. Pada pertemuan kedua peserta didik sudah mulai memahami pelaksanaan pembelajaran dan dapat menyimpulkan materi yang sudah dijelaskan. Pada pertemuan ketiga peserta didik terlihat aktif dan semangat saat berdiskusi. Pada pertemuan terakhir peneliti melakukan tes akhir (Postest) kemampuan pemahaman konsep matematis, peserta didik mengikuti tes dengan baik dan kondisi kelas dapat terkendalikan.

Pada kelas eksperimen 2 peneliti menerapkan metode peer tutoring. Pada pertemuan pertama kendala yang dihadapi penulis kegaduhan antar peserta didik yang berebut untuk meminta perhatian lebih, dan peserta didik belum terbiasa menggunakan metode pembelajaran peer tutoring. Pada pertemuan kedua, peserta didik sudah terbiasa dengan metode yang diterapkan tetapi peserta didik merasa malu ketika ditunjuk untuk maju kedepan menghadap guru. Pada pertemuan ketiga kendala sudah berkurang dan peserta didik sudah mulai mengerti tentang metode yang di terapkan. Pada pertemuan terakhir peneliti melakukan tes akhir (Postest) kemampuan pemahaman konsep matematis, peserta didik mengikuti tes dengan baik dan kondisi kelas dapat terkendalikan.

Pada kelas eksperimen 3, peneliti menggunakan buku saku digital. Pada penelitian pertama peserta didik diberi tugas kelompok untuk dikerjakan dengan menggunakan buku saku digital, tetapi mereka masih kurang memanfaatkan waktu karena saat di diberi tugas mereka sering terlihat mengobrol dan akhirnya diberi pemahaman untuk mengerjakan tugas terlebih dahulu. Pada 
pertemuan kedua peserta didik sudah mulai kondusif tetapi masih saja ada yang asik mengobrol satu sama lain. Pada pertemua ketiga peserta didik sudah mulai antusias, dikarenakan apabila peserta didik bisa menyelesaikan tugas dengan cepat dan dapat mengerjakan dipapan tulis peserta didik akan diberi hadiah oleh penulis. Pada pertemuan terakhir peneliti melakukan tes akhir (Postest) kemampuan pemahaman konsep matematis, peserta didik mengikuti tes dengan baik dan kondisi kelas dapat terkendalikan.

Pada kelas kontrol, peserta didik diberi perlakuan dengan menggunakan metode konvensional. Pada pertemuan pertama, kedua dan ketiga penulis memberikan materi dan beberapa soal guna memperluas konsep dari materi yang telah disampaikan. Kendala yang dihadapi yaitu kegaduhan antar peserta didik yang meminta perhatian lebih. Pada pertemuan terakhir peneliti melakukan tes akhir (Postest) kemampuan pemahaman konsep matematis, peserta didik mengikuti tes dengan baik dan kondisi kelas dapat terkendalikan.

Setelah penelitian baik di kelas eksperimen dan dikelas kontrol sudah selesai, maka penulis dapat menarik kesimpulan bahwa terdapat pengaruh metode pembelajaran peer tutoring berbantu buku saku digital untuk meningkatkan pemahaman konsep matematis siswa. Hal tersebut didukung dari hasil analisis data dan perhitungan yang telah dilakukan. Diperoleh hasil uji normalitas yang menunjukkan bahwa sampel berasa dari populasi yang berdistribusi normal. Karena keempat data berasal data yang berdistribusi normal sehingga dapat diteruskan dengan analisis selanjutnya.

\section{Penutup}

Berdasarkan hasil analisis data dan pengujian hipotesis yang telah dilakuka dapat disimpulkan bahwa adanya pengaruh penggunaan model pembelajaran Peer Tutoring method menggunakan media pembelajaran berbantu buku saku digital terhadap kemampuan pemahaman konsep matematis peserta didik. Adapun saran selanjutnya diharapkan dapat menerapkan dan mengembangkan pembelajaran Peer Tutoring method berbantu buku saku digital saat terjun dilapangan. Pemberian pujian atau reward bagi kelompok siswa yang paling aktif dapat digunakan sebagai pendukung pembelajaran. Selain itu, kreatifitas dan pengembangan media pembelajaran sangat diperlukan guna meningkatkan kemampuan pemahaman konsep matematis siswa, adapun diharapkan untuk penelitian ini dapat dijadikan sebagai referensi untuk penelitian selanjutnya.

\section{Referensi}

[1] Martinah, A. S., Kharisma, O. H., Nasution, S. P., \& Pahrudin, A. Pengaruh Model Pembelajaran Master Terhadap Literasi Matematis Ditinjau Dari Perbedaan Gender. (2019).

[2] Pahrudin, A., \& Syafril, S. Learning Content of Islamic Education Based on Multikultural in Senior High School in Bandar Lampung. Al-Tadzkiyyah: Jurnal Pendidikan Islam, 9(1), (2018), 81-91.

[3] Arnidha, Y. Analisis Pemahaman Konsep Matematika Siswa Sekolah Dasar Dalam Penyelesaian Bangun Datar. JPGMI (Jurnal Pendidikan Guru Madrasah Ibtidaiyah Al-Multazam), 3(1), (2018), 5361.

[4] Fitri, S., \& Utomo, R. B. Pengaruh model pembelajaran auditory, intellectually, and repetition terhadap kemampuan pemahaman konsep di SMP Pustek Serpong. JURNAL e-DuMath, 2(2), (2016).

[5] Sarniah, S., Anwar, C., \& Putra, R. W. Y. Pengaruh Model Pembelajaran Auditory Intellectually Repetition terhadap Kemampuan Pemahaman Konsep Matematis. Journal of Medives: Journal of Mathematics Education IKIP Veteran Semarang, 3(1), (2019), 87-96.

[6] Ishartono, B., Ashadi, A., \& Susilowati, E. Implementasi Model Pembelajaran Problem Solving Berbantuan Peer Tutoring Dilengkapi Hierarki Konsep Untuk Meningkatkan Kualitas Proses Dan Hasil Belajar Materi Stoikiometri Pada Siswa 
Kelas X IPA 6 Sman 1 Sukoharjo Tahun Pelajaran 2013/2014. Jurnal Pendidikan Kimia, 4(1), (2014), 10-19.

[7] Yuliana, N., \& Hamidi, N. Pembelajaran Kombinasi Tipe Pairs Checks dan Peer Tutoring Mampu Meningkatkan Prestasi Belajar Akuntansi Siswa SMA. Jurnal Pendidikan Ekonomi Universitas Sebelas Maret, 3(1), (2014), 13597.
[8] Husain, C. Pemanfaatan teknologi informasi dan komunikasi dalam pembelajaran di SMA Muhammadiyah Tarakan. Jurnal Kebijakan dan Pengembangan Pendidikan, 2(2), (2014).

[9] Sari, A. S. Pengembangan Buku Digital Melalui Aplikasi Sigil pada Mata Kuliah Cookies dan Candys. SCIENCE TECH: Jurnal Ilmiah Ilmu Pengetahuan dan Teknologi, 3(1), (2017), 46-54. 